\author{
JOURNAL OF ISLAMIC EDUCATION \\ Vol. 6 No. 2 November 2021 \\ P-ISSN 2503-5363; E-ISSN 2528-0465 \\ http://www. ejournal.stitmuhbangil.ac.id/index.php/jie
}

\title{
Education Based on Local Wisdom
}

\author{
*Moh. Toriqul Chaer ${ }^{1}$, Elfi Yuliani Rochmah ${ }^{2}$, Sukatin ${ }^{3}$ \\ ${ }^{1}$ (Sekolah Tinggi Agama Islam (STAI) Masjid Syuhada Yogyakarta) \\ ${ }^{2}$ (Institut Agama Islam Negeri (IAIN) Ponorogo) \\ ${ }^{3}$ (Institut Agama Islam (IAI) Nusantara Batang Hari Jambi) \\ *toriqul2108@gmail.com
}

\begin{tabular}{ll}
\hline Informasi Artikel & Abstract \\
\hline Received: & This article aims to examine the power of local \\
& wisdom in education. Local knowledge will only \\
last if local learning is applied concretely in & everyday life. Efforts to represent the concept of \\
Accepted: & education are not merely normative; only stated \\
31 May 2021 & and explained, but attempted performative form. \\
Published: & For example, local wisdom in education policies \\
5 November 2021 & $\begin{array}{l}\text { by the State is implementing character education } \\
\text { policies based on local knowledge, culture, and }\end{array}$ \\
Keywords: & culture This research is library research by \\
Deconstruction Theory, & making library materials the primary data source. \\
Education, Character, & The research data were obtained from several \\
Local Wisdom. & $\begin{array}{l}\text { pieces of literature related to the general } \\
\text { description of education in Indonesia, educational } \\
\text { problems and character education strategies. The } \\
\text { research data were analysed using descriptive- } \\
\text { analytical techniques with an inductive mindset. } \\
\text { Implementing efforts to conserve various } \\
\text { elements of local wisdom, traditions and local } \\
\text { institutions, including norms, customs and culture, } \\
\text { can function effectively in education. The goals of } \\
\text { education are based on local strengths and } \\
\text { characteristics that can advocate for disparities } \\
\text { and social-cultural discrimination in society and } \\
\text { contribute to better cultural education. }\end{array}$
\end{tabular}




\section{INTRODUCTION}

According to Inkeles (1966) in his book The Modernisation of Man, modernisation characterised specific trends, including (1) approval of a new and bold test of new methods and techniques, (2) expressiveness of opinions, (3) present and future-oriented than in the past, (4) appreciate the timeliness, and (5) planning, organisation, and efficacy. (6) see the world as it can calculate, (7) believe in science and technology, and (8) recognise the significance of equitable justice (Vygotsky, 2020).

The collective appearance of the eight criteria in a social institution characterises continuous modernisation. Chapter eight is a comprehensive attitude toward all aspects of society's beliefs, both personal and institutional, including education (Gurevitch, Bennett, Curran, \& Woollacott, 2021). As a result, as an institution, instruction takes on the mandate of "future ethics". The realisation that all human beings, as individuals and as a collective, will live the rest of their lives in the future and other living beings on Earth shapes the future of ethics. The end of ethics necessitates that a man accepts responsibility for the consequences (Tremmel, 2018).

As previously stated, the future's ethics are not the same as the ethics of the end; the ethics of the end is the present for the future. To respond to the challenge of a distinct ability to anticipate, formulate human values, and set priorities in an uncertain environment, the ethics of the future required a human being to dare to respond. Future generations are not victims of a process that will become increasingly unmanageable at a later point in time (Spitzer, 2007).

When discussing the future ethical context, an educational vision should be born to realise that humans should not wait for any future. The hope of the future expects us to set it up, and we should do so. According to Suyudi (2005), education is the entire conscious effort or activity carried out by educators to learners concerning all aspects of personality development (Schunk, 2012). 
Education is the interaction of man with his environment, which includes both the natural and human environments. The human interaction is aimed at interaction with fellow humans, but with the natural environment so that it can develop human potential optimally, the emergence of the notion of character education programs in Indonesia, understandable. Because, as long as it felt, the perceived educational process has not succeeded in establishing the Indonesian human character.

This condition requires an active response to empower Islamic education to respond. The ongoing campaign of character education should return to being the learners' spirit and motivation for personal good teachers and students in the educational environment (Ikhwan, Anwar, \& Mahmudah, 2021). Wherein any interactions enrichment even deepening educational characters can be started from where teachers and students were making the local characteristics of learners who will personally determine the essential growing knowledge and insightful intelligence nationality. It will be presented as the solution to a deterioration in the nation's morality.

The importance of an authentical national character effected: 1) The public's mutual culture is deteriorating; 2) The community's personality Shifts local (indigenous) by modernisation; 3) Change the norms and ethics of the association among the community; 4) The tendency of the ways anarchist (uncivilised) by a group of communities in submitting aspirations; (5) The weakening of the advocacy and educational accommodations manners informal education, non-formal, and informal; (6) As a result of economic disparity and low equity in certain societies, tolerance toward "promoting diversity" is eroding; (7) The emergence of some events indicating a weakening of the commitment to maintain the public interest.

That is the background to character education in the breakthroughs necessary to establish an authentic national character. The changes and developments in modern society inevitably impact the need for interpretation and a new understanding of the education system. However, they have also 
contributed significantly to the moral improvement of learners' quality as the next generation of the education system. Thus, this research attempts to bring the concepts of revitalisation and re-orientation of education to translate and advocate the national problems that occur at this time.

\section{METHOD}

The method used in this study uses a literature method or approach library research or literature can be interpreted as a series of library data collection methods, reading and taking notes and processing materials research (Mestika, 2003). In literature study research, at least four main characteristics of the authorised to pay attention (Moleong, 2005). First, the writer or researcher deals directly with the text or numerical data, not directly from the field. Second, library data is "Ready to use", which means that the researcher does not go to the area because the researcher faces existing data sources in the library. Third, that library data is generally the source secondary. The researcher obtains material or data from second hand and not data from the first in the field. Fourth, the library data condition is not limited by space and time (Widisuseno, 2012).

The approach was chosen based on the belief that the nature of social reality and the document's text is twofold, objective and subjective, or twotone, express (phenomena) and implicit (noumenon) (Webster, 2007). Of course, the methods required for interpretive epistemology must use to understand social phenomena or human behaviour unique to interpretation (Muhajir, 2000). The information gathered will include: (1) an overview of education in Indonesia; (2) issues with education in Indonesia; and (3) a strategy based on local wisdom on the nature of the discourse. Based on the preceding, the data collection in the study done by reviewing or exploring several journals, books, and documents (good in printed or electronic form) and other sources of data and or information considered relevant to the research or study (Bowen, 2009). 


\section{FINDINGS AND DISCUSSION}

Education is not life preparation, but life itself." So the opinion of John Dewey when he was trying to explain the realm of education. Education is a life process. Nevertheless, the process of education is often disconnected from the learners' world when learning to talk. Attempts to question the term "chalkboard educators that regardless of the question of life" have always been a compulsory question posed when building the educational world idealism.

The current educational process in schools continues to prioritise cognitive aspects over affective and psychomotor aspects. Even the national examination was becoming increasingly concerned with intellectual property issues. Even the national exam ever more concerned with intellectual property aspects rather than aspects of their honesty. We know the level of honesty that is simply 20 per cent of the National Exam because many students are cheating on the national exam in different ways. Even once found a few dishonest efforts of educators seeking National exam results from protected participants.

Character education must build a more civilised life, not a life filled with barbaric behaviour, as character education is known (character education). Education is forming a learner's character, involving at least the aspects of knowledge (cognitive), feeling, and action. Three elements include one unit that works together to form a whole. If one does not exist, character education will be ineffective. From the process of consciousness, a person learning about good values (knowing the good) and then feeling and loving-kindness (feeling and loving the interest) becomes so hardwired in his soul that it eventually becomes a solid breaker do good. Feeling and loving the good, i.e. turning virtue into power, can make people always want to do good.

Trace's history, leaders, leaders, and experts agree that global history characterises education as old as education itself. Socrates stated over 2,500 years ago that education's most fundamental goal is to make someone right and intelligent. Throughout Islamic history, the Prophet Muhammad has 
confirmed that his primary mission is to teach moral perfection and good character (Zukhrufin, Anwar, \& Sidiq, 2021).

However, the formation of characters as the fundamental goal of education is to lose by provoking positivism and relativism, believing that there is no moral truth and no right and wrong purpose and that all values are relative. Each person is free to determine their worth without being forced to do so by anyone. Each person is free to decide on their worth without being forced to do so by anyone. According to Howard, character education began to be the primary purpose of education in the 18th and 19th centuries, but the sinking occurred due to political issues and historical events. Similarly, the pattern of character education in Indonesia follows the ruling political era. For example, in the age of guided democracy, character education, also known as national and character building, was rolled out in learning P4. Education reform in the characters' era includes the competency-based curriculum.

The first vision of 8 national development visions is character education on the National Long-Term Development Plan 2005-2025. On several occasions, the President of RI has also revealed the importance of character development (character building) in Indonesia because he wants to build a human character, ethical and well behaved. Policy formulation on a national scale The national character development supports the implementation of the National Long-Term Development Plan 2005-2025 and the President of the Republic of Indonesia's Directives.

Following learning the character of education, which is critical to national education, a fundamental question about the sense of education itself arises. Character education is a type of education that focuses on the development of character values in students. The FW Forester formulates four essential character education traits at the end of the 18th century; First, the character education stressed any action against the holding's normative value. The student respects existing norms and based on such criteria. Second, to be consistent or instil trust and courage in students so that they become a firm 
foundation that does not easily sway and fear the risks that new situations present each time. Third, The student was living and practising the rule from the outside until it becomes personal in terms of values. Students can make their own decisions without being swayed by outside pressure-fourth, Constancy and faithfulness. Constancy is the longevity of the protégés to realise what is well seen. In addition, loyalty is necessary to respect the commitments made.

Character education is a process of transforming life's values to someone's personality in grew up so that it becomes one in the conduct of that person's life (Zurqoni, Retnawati, Apino, \& Anazifa, 2018). Within this definition, there are three critical thoughts idea, namely: (1) Process of Value Transformation, (2) Growing up as a personality, (3) One in the Behavior (Sari, 2013). Character education is an effort to guide human behaviour towards standard-standard form. The emphasis is on the character education objectives of ethics, but the practice includes developing necessary skills for social development, including students (Althof \& Berkowitz, 2006).

Based on the above exposure, it can be concluded that character education is not only intended to educate people to understand but to internalise these values in such a way as to form a character or a distinctive personality. It is true, in the end, that the success of character education is not just a stop to cognitive assessment, but how it could be character-forming human personality and civilised, in the opinion of Mardiatmaja, which states that the educational character is the spirit of education in the humanisation of man (humanist human). Because of its very complex and comprehensive nature, it should not be a mere formality or an end to developing values and norms for implementing nature education in environmental education. Please don't get stuck in the routine and obligations of abortion while the spiritual character of education itself is ignored. Therefore, character education should be supported by all elements of the nation, whether family, community, or government. 
A character formed through modelling and conditioning (habituation), so how could character education play an optimal role if there was no synergy between family, community, and government policymakers. Several steps can take to create quality human resources, which are as follows: (1). Maximise talent HR owned early on with implementing filtering the interest and aptitude; (2). The granting of appropriate educational talent human resources held; (3). The control and means of presenting and contracting talent; (4). Give direction and optimisation skill; (5). Giving business opportunities and facilitating HR capability if that minimum is already implemented, human resources capacity optimisation in Indonesia is impossible. At least reduce the rate of unemployment in Indonesia. Indeed by revamping the education system, this weak that impressed. It also addresses the cultural issue. Indonesia is the cultural skyscraper of the world. There is a wealth of diverse cultures and characteristics among different tribes and races (Najmuddin \& Aprilianty, 2020).

A variety of efforts can make to maximise culture's potential in Indonesia. One of them is the development of a Studio culture that can spread throughout Indonesia. It expects to open up new avenues for the development of Indonesian culture. Moreover, with the ratification and signing of the original cultural assets of Indonesia to UNESCO and continuing to accompany the sustainability of culture in Indonesia, it has become a valuable asset for an infinite price wealth. Become the wealth-producing opportunities of the country, and indeed become the national identity that boasts of its people.

The character of the crisis that occurred in this now is not yet the development of characters due to good behaviour patterns that are less good. As a result, a group or individual creating a reference for each. This condition is vulnerable to the problem. There is a collision, even horizontal conflict, for all groups claiming themselves as the dedicated community. In situations like these, characters often remembered the discourse, and subsequent developments tend to occur, the longer the increasingly alarming crisis. People 
realised that any good economic situation, fuel, food, environment, or health crisis stems from a spiritual problem and introduces ourselves to the absolute, i.e. God.

Plato said, "If you ask what the good of education is, generally speaking, the answer is easy, education makes good men, and good men act nobly." Prayitno and Manulang say, "The end of education is a character'. The entire educational program must gear toward character development. In the context of character development, intra- and extra-curricular activities should be carried out as a core unit of education (Prayitno \& Manulang, 2011).

A character cannot interpret a set of properties; instead, a character is a person's personality. Recognising the truth is the essence of education. All areas of study are like rivers. Spiritual education is analogous to the ocean. All rivers flow into and into the sea. The rivers lose their individuality when they merge into the sea ('Education and Culture | Sri Sathya Sai International Organization' 2011). The character should be viewed as the comprehensive properties, colouring the person's behaviour-a character concept's essence. If someone is a good character at home, they are also good in the community, at work, and elsewhere. When there are multiple personalities or two characters in one person, the character is more likely to be a clone, i.e. when the speech does not comply with the Act. The golden generation of characters expected the character's personality to be intact and original, with the address following the Act (Chaer \& Suud, 2020).

Character education fosters positive attitudes and normative thinking and should base on the IESQ capability. Understanding, action, and habits are all examples of positive attitudes. Understanding the main runway is IQ, while IESQ's unconventional IEQ Foundation is primarily SQ. The essential mindset consists of practical approaches, theoretical approaches, and approaches. Quick and accurate mental activity, thinking, reasoning, and problem-solving are intelligent intellectual characteristics. Numeric, verbal comprehension, perceptual speed, inductive reasoning, deductive reasoning, visualisation, and 
memory space are all intellectual capacity dimensions. An intelligence test can use to determine one's IQ.

Potential issues and interpersonal skills are referred to by the EQ. SQ relates to humanity's noble traits, and values are intelligence related to meaning and significance. Intelligence is more of the positioning of one's behaviour and life in the context of a broader and more complex definition.SQ is the foundation upon which IQ and EQ can function effectively. Controlling the entire program, infra- and extra-curricular activities, and institutional development can develop IESQ education strategies.

As the cover of this study, the author presents George Bernard Shaw's play Pygmalion, which deals with a Professor's efforts to help a woman "cheapo" named Eliza Doolittle become a respectable woman. Professor Eliza Doolittle's efforts to treat a good woman are the subject of this story. At the end of the story, the woman meets the professor's expectations. The film "Pretty Woman," starring Julia Roberts and Richard Gere, was inspired by the drama Pygmalion, which set the storyline between the interwoven love romance stories of a prostitute flamboyant saw. Goethe stated the preceding principles in the following sentence: "Even with someone as his appearance, he will undoubtedly be even uglier. However, even with someone who has been made possible by their potential, it will be so certain."

According to Goethe's statement above, someone was in an optimising capacity based on potential and talent. It would then be his most significant potential power to use for himself or the community's benefit. Regularly, a person's potential cannot measure by his or her physical appearance. Because a man creates potential and talent, potential and talent are unique things that become hidden abilities. If we correlated Goethe's statement with the golden generation of character formation efforts, it was also true. Offset generation and a potential, comprehensive, and talented student can be considered reference materials in print quality. Discussions cover not only scientific theories but also the growth of students' skills. When the educational process 
incorporates elements of character education, maximises IESQ, and accounts for both students' potential and talents, the country can produce a generation of high-quality gold with high morals and the ability to think and act intelligently.

\section{CONCLUSION}

Character education is an integral part of the nation that has written a piece of national education as a whole. National character education as a process culture should be developed comprehensively. Education and culture are therefore intact in the context of institutional needs. National character education is a shared responsibility between governments, communities, schools and parents. The four elements must therefore be involved in the implementation of the culture and character of the nation. Efforts to revitalise the nation's education needed a national movement to foster an evocative spirit of unity in the field. Islamic education as a system of education has not received enough contributions to support establishing a national character with a wide range of strategies and methods that are pretty profound.

Education can succeed with both, an-Nahlawi has tried to formulate knowledge and value of the various planting strategies. (a) teaching through the Qur'anic and Nabawi dialogues; (b) education through the Qur'anic and Nabawi stories; (c) education through models; (d) education through example; (e) education through practice and deeds; $(f)$ education through ibrah and mau'idzah; ( $\mathrm{g}$ ) education through targeted and tarhib.

The cultivation of the characters' values includes faith, Islam, insan, keishlahan and jihad, and has been reduced in the values that are praxis and supportive learning atmosphere: passion, discipline, kindness, benefit, and invites the truth. These values can be transformed through the role of the school principal as a leader Manager, the part of the environment consisting of the school, family, and society that can create an atmosphere of learning and the teacher's role in the learning process. Thereby implementing planting value 
of ongoing is accommodating, humanist, and giving spiritual reinforcement in religious conditioning at the beginning and the end of the study.

The cultivation of the character values in shaping the students' personality associated with the growing development of the moral capacity is unique and distinctive: the ever increasing pride in self-learners as citizens of the Union. This character's quality as being distinct that distinguishes ego learners from other people makes it capable of achieving progress or achievements that are both academic and non-academic.

Given the importance of character education, this program should be implemented, expected in directional, programmatic and integrated into the educational world and appropriately understood by teachers, parents, and the related Government Department synchronously implemented based on a shared commitment. Every teacher should understand the concept of characters both theoretically and practically and should be able to apply the values of the characters contained in the learning material to form the character of the learners. Educators of this type should provide formal, non-formal, and informal education.

\section{BIBLIOGRAPHY}

[1] Althof, W., \& Berkowitz, M. (2006). Moral Education and Character Education: Their Relationship and Roles in Citizenship Education. Journal of Moral Education - J MORAL EDUC, 35(1), 495-518.

[2] Bowen, G. (2009). Document Analysis as a Qualitative Research Method. Ualitative Research Journal, 9(1), 27-40.

[3] Chaer, M. T., \& Suud, F. M. (2020). Pendidikan Anak Perspektif Hamka (Kajian Q.S. Luqman/31: 12-19 dalam Tafsir Al-Azhar). Southeast Asian Journal of Islamic Education, 2(2), 125-141.

[4] Gurevitch, M., Bennett, T., Curran, J., \& Woollacott, J. (2021). Culture, Society and the Media.

[5] Ikhwan, A., Anwar, S., \& Mahmudah, N. (2021). Tahsin and Tahfidz Learning System at Integrated Islamic Elementary School ( SDIT ) Insan Madani During the Pandemic Covid-19. Al-Hayat: Journal of Islamic Education (AJIE), 5(1), 1-11. 
[6] Mestika, Z. (2003). Metode Penelitian Kepustakaan. Jakarta: Yayasan Obor Indonesia.

[7] Moleong, L. J. (2005). Metodologi Penelitian Kualitatif. Bandung: Pustaka Rosda Karya.

[8] Muhajir, H. N. (2000). Metodologi Penelitian Kualitatif. Pendekatan Positivistik. Yogyakarta: Rake Sarisin.

[9] Najmuddin, H. A., \& Aprilianty, L. (2020). The Analysis Of Learning Strategies For Character Development Of Students During Covid-19 Pandemic. Jurnal Tatsqif, 18(2), 136-150.

[10] Prayitno, \& Manulang. (2011). Pendidikan Karakter Dalam Pembangunan Bangsa. Jakarta: Gramedia.

[11] Sari, N. (2013). The Importance Of Teaching Moral Values To The Students. Journal of English and Education, 9.

[12] Schunk, D. H. (2012). Learning Theories: An Educational Perspective. Boston: Pearson.

[13] Spitzer, D. R. (2007). Transforming Performance Measurement: Rethinking the Way We Measure and Drive Organizational Success. New York: American Management Association.

[14] Tremmel, J. (2018). The Anthropocene Concept as a Wake-up Call for Reforming Democracy, https://doi.org/https://doi.org/10.4324/9781351174121-13 219-37.

[15] Vygotsky, L. (2020). Innovation and Creativity.

[16] Webster, M. (2007). Research Methods. Journal of Business, 5(3), 8.

[17] Widisuseno, I. (2012). Pendidikan Berbasis Multikulturalisme Suatu Upaya Penguatan Jatidiri Bangsa. Humanika, 15(1).

[18] Zukhrufin, F. K., Anwar, S., \& Sidiq, U. (2021). Desain Pembelajaran Akhlak Melalui Mata Pelajaran Pendidikan Agama Islam. JIE: Journal of Islamic Edication, 6(2).

[19] Zurqoni, Retnawati, H., Apino, E., \& Anazifa, R. (2018). Impact of Character Education Implementation: A Goal-Free Evaluation. Problems of Education in the 21st Century, 76(1), 88-99. 